\begin{tabular}{|l|l|}
\hline & \\
\hline
\end{tabular}

LIBERA

\title{
O horror passado permanece vivo: acerca de Setenta, de Henrique Schneider
}

The horrible of the past continues alive: it is about Setenta, by Henrique Schneider

\section{Alexandre Pandolfo ${ }^{1}$ \\ orcid.org/0000-0001-9415-7276 \\ acpandolfo@hotmail.com}

Recebido em: 25 out. 2019

Aceito em: 06 jan. 2020

Publicado em: 20 jul. 2020
Resumo: Este ensaio procura trazer à tona os elementos contemporâneos do romance Setenta, de Henrique Schneider, publicado em 2019, tratando de apontar algumas das principais imagens que o livro expõe. O romance desconstró a consciência apaziguada de um estado de coisas conduzido a sua repetição no Brasil em que vivemos, país ao mesmo tempo oligárquico e paupérrimo. Este ensaio trata de abordar a construção narrativa do romance e os problemas filosóficos e históricos subjacentes a ele, dialogando com algumas referências nacionais e internacionais sobre o tema da memória ética e do testemunho desde a perspectiva literária. Foca no caráter fragmentário do romance para lidar com o horror vivido no passado recente no Brasil e na América Latina, desde uma consciência crítica a respeito do tema, apontando para a necessidade estética de lidar com os traumas provocados na sociedade brasileira nesse período.

Palavras-chave: Setenta. Brasil. Romance. Ditadura. Tortura.

Abstract: This essay seeks to bring to light the contemporary elements of Henrique Schneider's novel Setenta [Seventy], published in 2019, trying to point out some of the central images that the book exposes. The novel deconstructs the appeased consciousness of a state of affairs led to its repetition in this Brazil where we are living in, a country at once oligarchic and very poor. From the literary perspective, this essay approaches the narrative construction of the novel and the philosophical and historical problems underlying it, dialoguing with some national and international references on the subject of ethical memory and testimony. It focuses on the fragmentary trait of the novel to deal with the horror experienced in the recent past in Brazil and Latin America, from a critical consciousness about the theme, pointing to the aesthetic need to deal with the trauma caused in Brazilian society during this period.

Keywords: Seventy. Brazil. Novel. Dictatorship. Torture.

"Imagine o senhor a dor de uma mãe que liga para o necrotério para saber se o seu filho está lá." (Henrique Schneider, Setenta)

1

Veio a público, no ano de 2019, Setenta, escrito por Henrique Schneider, mais um importante romance brasileiro que procura levar a cabo a tarefa de elaborar, por meio da articulação entre história, imaginação e memória, as atrocidades levadas a cabo pela Operação Condor. Lem- 
brando que suas asas, sabemos, sobrevoaram e impuseram-se sobre nosso território e regeram as práticas politicas ditatoriais assassinas na segunda metade do século XX em diversos países da América Latina e que hoje ousam, atrevem-se novamente a plainar sobre nós - o condor que ainda voa, a obnubilar a esperança de que uma tal barbárie não se repita.

Setenta, assim, entra para o rol das ficções literárias brasileiras que compõem uma espécie de arquivo da última ditadura. Conforme assinalou Eurídice Figueiredo, na sua ampla pesquisa sobre esse tema, um arquivo se monta a partir de vestígios, de rasuras, desde a "sobreimpressão de elementos como num palimpsesto" a ser composto, recomposto, significado e ressignificado junto aos "resíduos das experiências fraturadas pela violência" (2017, p. 29 e 44).

À ficção literária produzida para a elaboração desse passado recente de torturas, desaparecimentos e assassinatos promovidos pelo Estado em pleno acordo com grandes empresas nacionais e internacionais, acrescenta-se uma vasta produção teórica que procura exercitar (muitas vezes desde abordagens transdisciplinares, ensaiando e experimentado diálogos entre filosofia, psicanálise, história, direito, artes, etc) a inteligibilidade crítica de tais ficções, cujos corpos de linguagens tendem à aridez do testemunho, à radicalidade da expressão, bem como convergem às raias do absurdo plenamente realizável. A qualidade e a atualidade de Setenta contribuíram para que viesse a receber, em 2017, o Prêmio Paraná de Literatura. Seu autor, Henrique Schneider, possui também outros importantes livros publicados, os quais fizeram jus a indicações para outras relevantes premiações de literatura brasileira.

Setenta, pois, é um romance que se concentra em abordar um momento, a bem dizer, irrecuperável da passagem brasileira pelo horror ditatorial, dirigindo seu olhar às imagens do passado que relampejam no presente sem se deixarem nele fixar - lembrando o que escreveu Walter Benjamin em suas considerações sobre a legibilidade das imagens históricas (2018, p. 768 [N3,1]). Ressalto a seguinte colocação de Benjamin: "articular his- toricamente o passado não significa conhece-lo 'como ele propriamente foi'. Significa apoderar-se de uma recordação tal como ela relampeja num momento de perigo" (1994, p. 224 [Tese VI]).

O momento de perigo nos torna contemporâneos de Setenta, cujas imagens sincronizam o agora de uma determinada legibilidade sem sintese. A sua cognoscibilidade imagética, ao carregar consigo os momentos críticos subjacentes aos vestígios e aos restos da história para muito além das capacidades tradicionalmente entendidas como representacionais, são ancoradas em razões de ordem epistemológica, pautadas pelo domínio de uma consciência de si para si e para outrem plenamente comunicável.

O passado não é imediatamente cognoscivel "tal como propriamente foi", tal como seria o ideal de uma exatidão científica, de uma ciência burguesa comprometida com os ideais de totalidade e universalidade historicistas. Isso porque a ele precisam se articular as imagens dialéticas que, fora de todo controle ontológico apropriante, fazem explodir o continuum da história e, carregadas de temporalidade, transitam, deperecem, tornam-se ruínas: a legibilidade desde as ruinas faz liberar na coisa, no objeto, a materialidade da história, encontrando o agora num lampejo, exigindo da linguagem um comportamento constelar, uma montagem para a sua exposição.

Jeanne Marie Gagnebin (2006b, p. 40) enfatiza: "Nós articulamos o passado, diz Benjamin". Setenta, nesse sentido, refere-se ao ano, refere-se à Copa do Mundo, refere-se à década; à sociedade anestesiada, ao terror de Estado, às bárbaras torturas; refere-se ao sadismo, à perversão organizada junto aos aparelhos repressivos e autoritários comandados e empreendidos por autoridades ditas de bem, cidadãos ditos religiosos e familiares; refere-se ao desaparecimento, à busca de uma pessoa querida e à aparência de um erro, bem como, sobretudo, refere-se à continuidade indefinida na história desse mesmo erro. "Essas questões adquirem uma importância dolorosa (e não apenas epistemológica)" (GAGNEBIN, 2006b, p. 42). Em Setenta, a distância dos acontecimentos narrados torna-se infinitamente 
próxima e não cessa de colocar em cena o futuro junto às exigências de transformação do presente através de uma curiosa forma de expressão e de constelação das relações temporais.

2

Ao abrir o livro, o leitor depara-se com uma página preta, com letras garrafais brancas, anunciando uma declaração objetivamente mentirosa e escandalosa, hoje sabemos, ditada por Alfredo Buzaid, então ministro da Justiça no início da década de 1970, o qual "não há tortura no Brasil". Trata-se de uma sentença, por assim dizer, contemporânea, no sentido mais trágico do termo. Quer dizer, aquele sentido de acordo com o qual o negacionismo ardiloso e a sua repetição carregam consigo suas consequências catastróficas provenientes do facho de trevas histórico a alcançar um tempo agora, expondo-se a si mesma como farsa - performando a inteligibilidade e a governabilidade do mundo que deseja ser enganado.

Pensemos, aliás, o que significariam "ministro" e "justiça" para o consórcio militar-civil-midiático que comandou o terrorismo de Estado no Brasil a partir de 1964. Pensemos o que significam "ministro" e "justiça" nos dias de hoje.

(Então, exatamente no momento em que eu escrevia essas últimas frases, recebi por correspondência eletrônica uma matéria jornalística na qual mulheres presas em Ananindeua, no Pará, ano de 2019, fizeram chegar a público graves denúncias de torturas empreendidas no corrente ano, relatando que além de sofrerem espancamentos e insultos verbais em diversos momentos, também foram obrigadas a sentar em cima de formigueiros apenas de calcinhas, e a ficar cerca de até três horas nessa situação. Tais denúncias foram documentadas por vídeos realizados pela Ordem dos Advogados do Brasil, no Pará. Faço notar que uma tal atuação terrorista do Estado dentro de prisões vem sendo chamada de "procedimento" pelos seus executores). ${ }^{2}$
Isso importa para esse ensaio pela iminência do tema tratado no romance Setenta e, sobretudo, pela ideia de que, enquanto sociedade, ainda somos assombrados pela atualidade do terror empreendido sistemática e administrativamente por agentes do Estado. ${ }^{3}$ Assim como somos assombrados pela farsa.

Trata-se, pois, de tentar fazer o leitor chocar-se (palavra ignóbil nesse contexto) com as atrocidades levadas a cabo em nome de um Estado de fato fascista. Desde uma determinada compreensão de um tal estado de coisas que, além da força física bruta, sádica e assassina contra determinadas pessoas, contra outrem propriamente dito, utiliza-se de um aparato de linguagem e de comunicação muito bem estabelecidos para conduzir um regime totalitário baseado na primazia da mentira.

Lembro de Jacques Derrida, que no texto de uma conferência trazida ao público pela primeira vez no Brasil, proferida no Museu de Arte de São Paulo, no ano de 1995, intitulada História da mentira: prolegômenos, trabalhando com os pensamentos de Kant, Nietzsche, Arendt e Koyré, abordou uma questão das mais radicais para a filosofia e para a história, a saber, aquela que se envolve com a ética da memória política e, sobretudo, com a crise e crítica das razões de Estado, digamos que maquiavelicamente entendidas. $\mathrm{O}$ tema de fundo do texto de Derrida trata, pois, do uso da mentira e, portanto, também do uso da verdade no que concerne ao reconhecimento do Estado por crimes cometidos pelo próprio - o texto reflete sobre o arquivo desses crimes.

Derrida aponta que na história da filosofia é bem conhecido "o fato de que a política é um lugar privilegiado para a mentira" (1996, p. 11) e que, como havia demonstrado Hannah Arendt (1995, p. 23) a esse respeito, "a manipulação moderna dos fatos (...) generaliza uma espécie de mentalidade da raison d'etat", para a qual, nos dias de hoje, a prática do mentir conduz, dentre outras coisas, 
a uma espécie de substituição do que foi, uma troca, uma permuta atinente ao experienciado que passou e aconteceu, substituição levada a cabo por uma determinada revisão disso para a história, uma reescrita negacionista no mais, ditada diante dos- e sob os olhos dos outros: "sob os olhos daqueles que dela foram testemunhas" (ARENDT, 1995, p. 21). A atualidade dessa questão, parece-me, é justamente aquela de que somos contemporâneos ao abrirmos Setenta e nos depararmos com o que nos deparamos.

O estatuto filosófico-político da mentira Moderna, cujo desenvolvimento vem se desdobrando há séculos no mundo ocidental, tornou-se hiper-fake-comunicativo nas sociedades tardias tais como são as nossas. A mentira ou a denegação no sentido político já não se destinam mais, meramente, à dissimulação de fatos talvez de todo não conhecidos pelas pessoas em geral ou pela sociedade mesma, por assim dizer, encobertos para priorizar a aparência de uma realidade mais agradável "para inglês ver". Mas sim, como escreveu Derrida, nesse âmbito levando adiante as proposições provenientes do pensamento de Arendt, a situação macropolítica da mentira hoje movimenta-se e estrutura-se para a substituição própria-imprópria do sentido de realidade empiricamente vivido (DERRIDA, 1996, p. 14), ao mesmo tempo em que captura a crise entre verdade e mentira para uma arena mítica (DERRIDA, p. 30 e ss, especialmente nota de rodapé n. 27) e moralmente auto-afirmada, definindo-se junto aos conceitos de nacionalismo, patriotismo, identidade, dentre outros.

Sabemos que para as razões de Estado dos sistemas totalitários a substituição dos sentidos de realidade vivenciados pela falácia discursiva hipercomunicativa é operada não apenas de fato, mas, sobretudo, de direito. E que essa substituição opera desde ideia de um passado-presente coeterno ancorado no indicativo ontológico do verbo ser atuando por sobre o passado e por sobre o futuro por meio da destruição dos sentidos de realidade deveras experienciados pelos sobreviventes, concomitante à imposição formal de um discurso que nada precisa preservar da verdade objetiva - trata-se da destruição de uma memória por assim dizer testemunhal e, ao mesmo tempo, de uma etapa da construção, edificação e estabelecimento do discurso chamado historicista (a saber, por vezes, ahistórico) de produção de uma memória monumental: uma luta pelo arquivo.

Deveriamos, pois, compreender que, para nós, imiscuídos ao fenômeno das massas e aos jogos hipercomunicacionais para uma sua manipulação, "as coisas pareceriam ainda mais desesperadas do que Platão as supunha", escreveu Arendt ironicamente (1995, p. 10). A prática do enganar, do iludir e do falsear com fins politicos consegue converter e distorcer a bel prazer o presente e o passado e, enquanto tal, tornou-se a característica capital dos sistemas totalitários de Estado. O controle social é, assim, empreendido pelo apagamento, desaparecimento e aniquilamento da alteridade - logrando promover um efeito de verdade indubitável, kafkianamente falando.

\section{3}

A narrativa desdobrada em Setenta encontra-se montada de forma fragmentária, intervalar e não cronológica. Somos constantemente levados, micrologicamente, a um passado e a um futuro recentes, cujas extensões, porém, mesmo ao final do livro, tornam-se dificeis de controlar.

Estamos, pois, apenas aparentemente adstritos, no romance, a cerca de duas semanas que (se pudéssemos tornar linear) transcorrem no mês de junho, desde uma festinha de criança, no dia 9 , que localiza o ambiente familiar do personagem carcereiro, turvando a personalidade psicopata deste, ironizando seus valores e suas disposições assassinas ${ }^{4}$, até o dia da final da Copa do Mundo de futebol, jogo entre Brasil e Itália, no dia 21, dia da soltura de Raul dos Santos Figueira, preso e torturado por "engano".

Apenas por um instante no romance somos

4 Importante enfatizar mais uma consideração histórica de Eurídice Figueiredo: "O que me parece relevante abordar é como as autoridades do país deram carta branca a policiais e militares, muitos deles verdadeiros psicopatas, a fim de eliminar pessoas de forma sistemática, simulando teatrinhos ou descartando os corpos [...]" (Op. Cit, p. 14). 
conduzidos literariamente para fora desse curso temporal, a cada momento em si mesmo intervalado, ao lermos uma passagem transcorrida no dia 4 de abril do mesmo ano, contando da tentativa (frustrada) de sequestro do cônsul estadunidense em Porto Alegre, cena esta que está ali retratada porque visa explicitar de certa forma as razões autoritárias de Estado para o emprego metódico do desaparecimento e da tortura, tal como narrados no livro. As entradas de cada capítulo do romance são precedidas pelas informações a respeito do local, data e hora em que se passa o evento a ser narrado a seguir.

Devido à forma que tais informações adentram a narrativa, como num relatório objetivo e público, com letras maiúsculas simulando as de uma máquina de escrever num fundo em preto esfumaçado (talvez queimado em suas margens), temos a impressão de que estamos a abrir uma espécie de arquivo histórico. O romance torna-se assim um corpo-arquivo de linguagem, um corpo de memória.

Raul não sabe por que foi preso. Ele é um bancário que não se interessa por política. Mora coma mãe, de quem é filho único. Teve uma namorada que terminou o relacionamento com ele há três meses. Esse término abrupto sugere na montagem do texto, de modo obliquo, alguma coisa a respeito da relação dela com a malfadada tentativa de sequestro, tendo ela sumido "sem deixar rastros".

O narrador jamais aponta isso de forma explícita, apenas fala do estranhamento da mãe em relação à namorada do filho e da camiseta que ela presenteou ele, justamente a que ele vestia quando foi capturado, confundido com alguém que usava uma camiseta semelhante, "vermelho berrante". Essa sugestão não se torna de fato uma questão no romance, apenas aparece ali como elemento de fundo para a composição da trama.

Raul ainda sofre com o término do namoro e ele é sequestrado pelos agentes do Estado no dia dos namorados. O narrador bem aponta que não adianta Raul insistir que ele não é comunista, que ele não se envolve de forma alguma com política, que ele tem os seus direitos, "pelo amor de Deus", que é trabalhador, que é de família e pagador de impostos.
Sequestrado por policiais a serviço do Estado na guerra contra o comunismo, contra os subversivos "comedores de criancinhas", Raul teria apenas uma oportunidade, a de confessar o que os seus algozes presumiam já saber. Interessante notarmos a aparência de uma proposição histórica irônica a esse respeito: que "até uns dias atrás, Raul nem sabia que existiam razões para derrubar o governo. Tudo ia bem no país, bem como diziam a tevê, o rádio, os jornais" (Ibidem, p. 148) - até que adveio o momento em que ele começou a entender.

Já na primeira noite de sua prisão Raul tomara consciência de que estava no inferno, como aponta o narrador: numa cela úmida, depois de socos e pontapés tomados, cuspido, vencido, ele "apenas arregalou os olhos no meio daquele pesadelo" (Ibidem, p. 30). Essa imagem, de certa forma cristaliza, ainda no início do romance, o jogo de luz e sombras, claridade e bolor - Sol, umidade e cegueira que irá se repetir, de acordo com uma interessante proposição narrativa imagética, e junto a qual se agrega a figura de um tecido, um capuz, o qual seus algozes impõem sobre a cabeça de Raul logo que ele é capturado e que lhe deixam enigmaticamente em posse por fim capuz "suarento e rançoso", conta o narrador, que provoca "engulho", evocando presenças ausentes, vale dizer, evocando a memória de "gente sangrando, espancada, chorando, quebrada, salivosa e ranhenta" (Ibidem, p. 22). Raul era mais um. Agora, contudo, quantos precisarão ainda passar por isso até hoje não podemos ter certeza - e tal é o assombro que nos causa a irresolução do horror no passado repetindo-se no futuro.

A mãe de Raul, obviamente, saiu à procura do seu filho. Foi à delegacia, ao jornal, à igreja. Mas, nada nem ninguém podia de fato ajudar a resolver o desaparecimento do seu ente mais precioso.

Ela levava consigo um retrato dele, ao mesmo tempo sinal da sua identidade inconfundivel e (o que saberia ela, afinal?), talvez, rastro penúltimo de um rosto para sempre desaparecido assumindo a forma de uma imagem. A fotografia, nesse caso, torna-se um elemento minúsculo e de crucial importância para a inteligibilidade crítica do romance, porque transita da lógica da identidade 
apropriante, que serviria aos designios de controle social por meio do aparato repressivo autoritário do Estado, para a lógica da denúncia dos desaparecimentos forçados, conforme já apontou Márcio Seligmann-Silva (2009, p. 319) a respeito da "sobrevida fotográfica dos desaparecidos nas ditaduras civis-militares na América Latina". ${ }^{5}$

Portando uma fotografia do filho, a inominada mãe de Raul sai em busca dele. E isso lembra os rostos daqueles que jamais voltaram para casa, e cujas faces fotografadas restaram estampadas em cartazes empunhados por suas mães, como no caso emblemático das Madres de la Plaza de Mayo. A atuação dessa mãe, em Setenta, traça, delineia, pois, as dimensões de uma fragilidade subjetiva frente ao terror objetivo.

E é relevante apontar que em todos os momentos nos quais a mãe aparece atuando no romance o narrador como que se ausenta ou se retira de cena e deixa que se apresente uma espécie de monólogo da mulher, deixando assim transparecer a angústia existencial na qual ela se encontra. A esse respeito, gostaria de fazer notar que, por um momento, a mãe de Raul, quem até então no curso entrecortado do romance sempre havia se demonstrado absolutamente confiante na injustiça, fosse como fosse, que acometera o destino de seu filho, duvidou desta confiança.

Rumo ao desfecho do romance, a mãe de Raul aparece conversando com a sua vizinha (que the ajuda com as ligações telefônicas e em tudo mais o que pode): lemos apenas a digressão aflita e consternada da mãe, dizendo para sua amiga o que não ousara dizer nem para o padre, nem para o jornalista, nem para a policia, a saber, o seu medo de que Raul tivesse sido cooptado por um desses grupos comunistas, guerrilheiros, subversivos, etc. - "E na verdade nem é uma desconfiança", ela diz, "porque eu puxo da memória e não encontro nada que possa me fazer pensar assim, e nunca encontrei nada de comunista nas coisas dele. Mas não sei, nunca se sabe, aquele sumiço repentino da namorada..." (SCHNEIDER, 2019, p. 143).

Essa circunstância torna iminente o perigo da situação na qual se encontra Raul. Historicamente sabemos que diversas pessoas capturadas, torturadas e desaparecidas pelos regimes impostos na América Latina durante a Operação Condor foram denunciadas por pessoas próximas, parentes ou vizinhos, tendo ou não envolvimento de fato com a resistência ao terrorismo institucionalizado. E que meras suspeitas sem sentido poderiam levar a situações absurdas, tais como estas que conhecemos ao lermos Setenta.

Além disso, é típico do tratamento abusivo dos regimes totalitários, como vimos, no que concerne ao uso da linguagem, da memória e do conhecimento de si e do outro, para si e para o outro, a distorção própria dos sentidos dos acontecimentos vividos, a mentira contada mil vezes (com o apoio dos meios cada vez mais inovadores de comunicação e dominação das massas) para que um tal embuste, uma tal falácia ou farsa a respeito de alguém, a respeito de outrem, torne-se qualquer espécie de vir assim a ser uma "verdade", ainda que contrariando as vivências, os conhecimentos e as estruturas de segurança mais intimas que tenham sido compartilhadas, por exemplo, por familiares os mais próximos. Essa estrutura de desconhecimento e desmemória, de quebra de relações e de produção fake de inimigos, vige até os dias de hoje.

Dialogando com o romance $K$ - relato de uma busca, de Bernardo Kucinski (que nomeia a permanência dessa situação já no início da sua narrativa), podemos dizer: trata-se "não de um lapso ou falha (...) e sim de um mal de Alzheimer nacional" (2010, p. 12).

4

A referência ao $K$, de Kucinski, deve levar mais para fundo na própria obra de Schneider, Setenta. A temporalidade própria a cada um desses

\footnotetext{
5 Cito mais um pouco desse importante texto de inspiração benjaminiana: "Levando em conta que aquilo que está para desaparecer assume a forma da imagem, podemos pensar na fotografia como arte da desaparição. (...) As fotos de identificação, criadas no final do século XIX para controlar as populações, foram transformadas na América Latina em poderosas fontes documentais para comprovar a existência dos desaparecidos. (...) A fotografia teve papel decisivo, nesse quadro, enquanto meio de resistência e oposição à ditadura. (...) na ditadura as fotos têm um papel de denúncia. São testemunhos no sentido jurídico de testis. (...) a apropriação destas imagens depois das ditaduras está subordinada a um trabalho - sempre conflitivo, político - de memória" (Op. Cit., p. 319).
} 
romances se deixa permear por imagens evocadas em variações de romances outros que se envolvem com esse periodo histórico das guerras quentes da segunda metade do século XX na América Latina e Central.

Foi assim que, ao ler Setenta, me vi conduzido ao romance Ana sem terra, de Alcy Cheuiche. Ele lida com o mesmo tema e possui também uma interessantíssima composição temporal da sua narrativa.

Mas essa afinidade, essa associação, ocorreu-me, principalmente, porque há uma cena do terror de tortura em Ana sem terra, horripilante, sádica, que faz coincidir futebol e perversão. Ela se passa no mesmo dia em que Raul é liberado, em Setenta, o dia da final da Copa do Mundo de futebol entre Brasil e Itália, no México.

Essa transferência temporal das cenas de terror, de um livro para o outro, inscreve-se junto aos limiares próprios da representação, junto aos jogos miméticos, ao funcionamento, à organização e à distribuição pela linguagem de uma crise radical de sentido. Para Marcelo e Maren Viñar (1992, p. 73), a tortura, sendo parte de um projeto político e de um sistema de poder, torna-se um instrumento: "seu objetivo é provocar a explosão das estruturas arcaicas constitutivas do sujeito, isto é, destruir a articulação primária entre o corpo e a linguagem".

Difícil e arduamente levadas à letra, a radicalidade da dor experimentada na tortura, a sensação de irrealidade de uma forma extrema de sofrimento, "o trauma, por sua própria definição de real não simbolizado"6, como escreve Maria Rita Kehl (2010, p. 126), encontra, contudo, na literatura, na forma poética, a sua concha acústica, a sua transvaloração, o tempo-espaço de uma sua escuta e reverberação por meio da linguagem. Para Roberto Vecchi (2012, p. 251), nesse sentido, "entre o infinito do massacre e o finito da escrita do massacre sempre há um resto irredutivel que resiste à representação", motivo pelo qual, afirma: "o poder da escrita é um poder sobre o horror" (Ibidem, p. 252).

A literatura, assim entendida como a ficção na letra e a fricção da realidade, corpo de linguagem, corpo de memória, é ao mesmo tempo convocada a dizer e limitada no seu processo. Com isso, torna esta a condição básica para uma sua elaboração critica, jamais estável, atualizando-se para além da determinação indicativa do verbo ser - o que torna legivel na letra a crise da representação e as condições para o exercício da sua crítica agora, quer dizer, para o exercicio literário in extremis.

A narração, então, de uma cena de terror de tortura defronta-se corporalmente com os paradoxos que concernem propriamente às literaturas de testemunho, literaturas de memória política, comparadas e nacionais, convocadas a lidar com a questão do "irrepresentável" que é no fundo, pois, o tema da representação e da historiografia das narrações do horror humano enquanto tal. Esse ponto estético imbrica-se historicamente à memória e à ética políticas.

A sua narração toma corpo no sofrimento que precisa passar, em múltiplos sentidos; e a escritura, a ficção e os seus vestígios, os restos irrepresentáveis que lhe assombram, tornam-se as vias capazes de transmitir o âmago da experiência histórica, o sofrimento que pesa sobre tais obras narrativas. $E$ isso se envolve criticamente também com os descasos e as tratativas lógicas para dominar ou denominar, circunscrever e mesmo realizar o sofrimento enquanto tal, política e epistemologicamente falando, envolve-se de modo fundamental com o fato de que algo escapa às pretensões cognitivistas, positivistas, logocêntricas, anestésicas da consciência, por assim dizer, tornando-se ainda mais, outra vez, a literatura, a chave do tempo - a chance da desconstrução da tautologia de uma violência dominante e operante ontem e hoje.

Em Setenta, Raul foi torturado fisicamente em duas diferentes ocasiões enquanto esteve preso. Primeiro como cobaia, como corpo dócil de experimento de determinadas técnicas a serem empregadas doravante pelos agentes de Estado ali dispostos. E, depois, na condição própria de interrogado, como corpo entregue à procura de uma "verdade" confiada aos seus carrascos agentes de Estado.

\footnotetext{
6 Kehl também escreve o seguinte: "Quando se trata de experiências-limite é preciso escutar os poetas. Torquato Neto, por exemplo: 'Leve um homem e um boi ao matadouro; aquele que berrar é o homem, ainda que seja o boi'" (Op. Cit., p. 131).
} 
Na primeira vez, conta o narrador, que Raul fora conduzido, sem algema ou corrente, por corredores escuros: que ele, de antemão, "percebia que aquilo parecia o porão ou a masmorra de algum casarão assombrado no qual ele mesmo era um dos fantasmas" (SCHNEIDER, 2019, p. 95). Ao entrar numa sala também escura e úmida, Raul viu jovens aprendizes abancados ali, eram os seus algozes.

E essa primeira cena de tortura é toda permeada pelas lições de um expert, o doutor Pablo, que viera do centro do país justamente para uma tal lição: explicar as técnicas e seus métodos profissionais, que deveriam ser racionalmente executados. Nessa ocasião, o expert torturador demonstrava estar procurando ao máximo se conter, ainda que, para Raul, o absurdo sem retorno houvesse sido alcançado de fato: pau de arara, choques elétricos, soqueira, enquanto o torturador enfatizava a criatividade para seus aprendizes alcançarem bons resultados e bradava que o pau de arara era uma contribuição genuinamente brasileira - então, "um dos homens aplaudiu e gritou 'viva o Brasil!'" (Ibidem, p. 99).

Dois dias após essa primeira sessão, Raul foi novamente submetido a uma tal imposição calculada do horror inominável. Dessa vez tratava-se de fato de um interrogatório aos moldes jurídico- políticos do terror instituído em busca de uma "verdade". Raul encontrava-se definitivamente na condição de um corpo assujeitado, entregue ao arbitrio e à crueldade. Ele não poderia jamais responder o que seus torturadores esperavam, porque a sua situação era a de alguém que não sabia nada do que the era imputado, porque o seu sequestro era de fato um "erro" cometido pelos próprios agentes autoritários.

Mas a ignorância de Raul soava como tentativa de heroísmo aos seus algozes, como observa o narrador. Raul era um desgraçado. Os torturadores, especialmente um deles, conhecido como Raposo, o mais sádico ali presente dentre os sádicos de Estado, gozava da maneira atroz com a tortura de Raul, o que obviamente, como de praxe, excedia as finalidades pragmáticas de obtenção de informações.

Raul estava no pau de arara, sofrendo choques elétricos, socos e apanhando também com um bastão de madeira. "O torturador encaixou com certo cuidado o alicate no dedo mínimo do prisioneiro e apertou-o com força num movimento rápido. Raul gritou sem dizer nada, um urro animal, e naquela hora pensou que fosse perder os sentidos" - essa situação com o alicate durou cerca de um minuto até formar-se uma "massa de sangue ao redor do dedo do prisioneiro" e o chefe fazer sinal para que Raposo parasse (Ibidem, p. 123).

Raul uivava com uma força ele já não tinha, alerta o narrador. E tomava mais choque. Ele não sabia, nem tinha o que dizer. Segundo Maria Rita Kehl, "a fala que representa[ria] o sujeito deixa de the pertencer, uma vez que o torturador pode arrancar de sua vítima a palavra que ele quer ouvir" - arrancam-se unhas, dedos, dentes, mamilos, em nome da ordem e do progresso, em nome da verdade das estruturas do capital - "resta ao sujeito preso ao corpo que sofre o silêncio, como última forma de domínio de si, até o limite da morte. E resta o grito involuntário, o urro de dor" (KEHL, 2010, p. 131).

Em Setenta, lemos que, após um dos torturadores derramar um balde de água sobre o corpo de Raul, este "começou a tremer sem controle, aumentando a dor dos punhos e tornozelos, pelos quais estava pendurado (...) era um tremor sem destino, inteiro abandono, como se estivesse em permanente choque" (SCHNEIDER, 2019, p. 125). Após o que, mais choque elétrico, com fios fixados no nariz, nos testículos e no ânus.

Terminada essa sessão de tortura, a qual é preciso ler propriamente junto à montagem do romance, Raul prostrado no chão, desfalecido, o narrador faz notar que nenhum dos torturadores "quis sujar as mãos para levantá-lo" (Ibidem, p. 145). E essa imagem torna-se crucial. Ela aponta para a irresponsabilidade pela atrocidade praticada, aponta para o percurso brasileiro e latino-americano em direção à indigência extrema, dirigido por conhecidos patrões desde o exterior, executada no interior, no intestino, na carne infinitamente machucada, transformada em excremento e ausência para si própria. Essa imagem aponta para a barbárie civilizatória e totalizante que mutila, unifica e anestesia a cons- 
ciência social (PANDOLFO, 2017, passim) - e gera um conhecimento contíguo ao esboroamento da fronteira entre ficção e realidade: a concepção fascista da história precisa ser destruída.

\section{5}

Em Setenta, desde o início sabemos, devido à sua composição fragmentária e cronologicamente não linear, que os perversos torturadores agentes do terrorismo de Estado, ao "liberarem" Raul, insistem ainda em amedrontá-lo. Certamente de forma indefinida - num para sempre, tal como permanecem as suas "chagas vivas em todo o corpo" que levarão a "eternidade para curar" (SCHNEIDER, 2019, p. 9) - dizendo que ele deve estar muito ciente de que "isso que tá acontecendo nunca aconteceu!" (Ibidem, p. 12), o que é repetido muitas vezes e forçado com tapas na cabeça de Raul, enquanto ele está no carro com seus algozes, vestindo aquele capuz nojento na iminência de ser atirado para rua, na sarjeta, na manhã do dia do jogo da final da Copa do Mundo.

Ao sair do carro, ou melhor, ao ser empurrado para fora do carro, Raul está obviamente desmontado, desarticulado, na miséria, sentindo em si todas as dores do mundo. Ele não poderia voltar para a casa antes das 21 horas, como haviam ordenado os agentes perpetradores do sequestro e da tortura. Num estado perdido e esfomeado, Raul vai até uma lancheria, na qual se reúnem em rebanho bandos de torcedores da seleção brasileira de futebol.

E, como não tem fim o martírio de Raul, pouco tempo depois de sentar e começar a comer algo, o carcereiro que até então o violentara entra ali, agressivo, seguro de si, perverso. E diz para Raul que, naquele dia em que a seleção se consagraria tri campeã, "o resto não existe. Entendeu? Não existe!" (Ibidem, p. 136). O narrador aponta, assim, com muita perspicácia, a configuração da "extensão esportiva das sessões de tortura" (Ibidem, p. 137). ${ }^{7}$

O que eu gostaria de enfatizar, contudo, nesse momento, é a dinâmica da repressão imiscuída ao recalque que conduz à repetição do horror no presente e no futuro. A disposição em negar os atos terroristas ocorridos em nome do Estado e do capital, "o gesto de tudo esquecer e perdoar", como assinala Theodor Adorno (1995, p. 29), no seu conhecido texto a respeito da elaboração do passado de terror nazista, sempre "acaba advindo dos partidários daqueles que praticaram a injustiça", seja da parte dos executores de fato, seja da daqueles que agora pretendem não ter tido o conhecimento dos fatos, na ocasião. "O esclarecimento acerca do que aconteceu precisa contrapor-se a um esquecimento que facilmente converge em justificação do esquecimento" (Ibidem, p. 45), tautologicamente alimentado.

O principio interno da racionalidade governamental autoritária, torna-se, como sabemos, a destruição da memória. Esse é um dos motivos pelo qual os assassinos e torturadores querem impor às suas vitimas a subtração das suas lembranças, das recordações as mais dificeis e das suas formas de elaboração, a imposição ousada e perversa de um tal não ter sido o que foi - sentido na carne.

Essa imposição forçada do esquecimento, do silenciamento, tentativa de apagamento dos crimes e das dores contribui para perdurar o tormento e fazer repetir o passado atroz no presente e no futuro. Nesse percurso, como escreveu Adorno, "a humanidade se aliena da memória esgotando-se sem fôlego na adaptação ao existente" (Ibidem, p. 33), quer dizer, na identificação com o poder autoritário enquanto tal.

Segundo Gagnebin (2006a, p. 103), "a exigência de não-esquecimento (...) é uma exigência de análise esclarecedora que deveria produzir instrumentos de análise para melhor esclarecer o [momento] presente". A esse respeito, o acontecido catastrófico do qual os seus perpetradores desejam escapar à memória, permanece, pois, atual e muito vivo nas democracias que, de forma ambígua, acabam corroborando para o retorno da barbárie civilizacional com suas políticas da amnésia conciliadoras. Porém, a determinação do

Existem muitos relatos a esse respeito. Documentários como, por exemplo, "Memórias do chumbo: o futebol nos tempos do Condor", de Lucio de Castro; também romances abordam essa temática, como Dos veces Junio, de Martin Kohan, por exemplo. É muito conhecido também que o Estádio Nacional do Chile foi usado como campo de concentração e tortura de prisioneiros a partir de 1973, quando a Operação Condor leva a cabo o golpe de estado que depõe Salvador Allende. 
esquecimento, a saber, a anistia propriamente dita, como afirma Gagnebin (2010, p. 180), "não consegue o que sua semelhança fonética com o termo amnésia promete", seja porque a luta pela memória se torna vital para a sobrevivência, seja porque o recalque dessa luta se torna catastrófico com a sua repetição iminente, a olhos vistos ou não.

Nesse sentido, para Kehl (2010, p. 126), "não há reação mais nefasta diante de um trauma social do que a política do silêncio e do esquecimento, (...) esse simulacro de recalque coletivo tende a produzir repetições sinistras". Quando Raul encontra-se na rua, "liberado", ele pergunta-se intimamente "o que lhe havia acontecido e o que ainda podia acontecer" (SCHNEIDER, 2019, p. 16), e se dá conta do seguinte: "ninguém aqui nesta rua sabe o quanto eu sofri!" (Ibidem, p. 40).

Depois, ao término do jogo, quando é novamente "liberado", pelo carcereiro perverso, como se uma tal soltura se constituisse ela mesma de uma repetição infinita e nunca realizada, o narrador nos aponta que esse mesmo carcereiro cisma que jamais deveriam ter soltado Raul: que ele não vibrou nenhuma vez durante os três gols do Brasil e que por isso devia ser comunista mesmo e que isso precisaria ser relatado ao chefe e que "talvez fosse preciso prendê-lo outra vez" (Ibidem, p. 140).

Segundo Adorno (1995, p. 49), "o passado só estará plenamente elaborado no instante em que se estiverem elaboradas as causas do que passou", a saber, as relações concupiscentes entre Estado, capital e direito; entre nação, mito e rito. Tais relações não passaram jamais pelas formas institucionais de elaboração necessárias para uma espécie de constituição objetiva que pudesse vir a evitar a repetição catastrófica do horror no Brasil.

E é nesse sentido que, como apontou Paulo Arantes (2010, p. 210), o ano de 1964 veio a ser "o verdadeiro ano que de fato não terminou. Um tempo morto, esse em que a ditadura não acaba nunca de passar", seja porque os carrascos nunca foram julgados, seja porque, normalizada a violência política, a "abertura" democrática veio a consolidar um modelo de estado de emergência econômico permanente, alastrando-se "a demência assassina do aparelho repressivo" à "tipologia indefinidamente elástica de urgências regidas pela lógica leconômical do excesso" (Ibidem, pp. 220, 225).

Esse ano que não terminou, e que podemos remeter à 64, à 68 e a 70, a passagem indefinida pelo horror que podemos remeter também ao ano de 1.500. Essa passagem que se estende agora, diante de nossos olhos e pés, o estado oligárquico lamaçal das coisas no Brasil, contudo, ganha expressão estética no romance Setenta e desafia relações e comoções reciprocas entre a realidade social e a indignação ética frente ao terror. Uma tal relação ético-estética, portanto, politica, filosófica e literária, torna-se capaz de despertar agora centelhas de esperança na luta contra o fascismo, sabendo que nos dias de hoje sequer os mortos e desaparecidos restam em paz.

\section{REFERÊNCIAS}

ADORNO, Theodor. O que significa elaborar o passado? In: ADORNO, Theodor. Educação e Emancipação. Tradução Wolfgang Leo Maar. Rio de Janeiro: Paz e Terra, 1995.

ARANTES, Paulo. 1964, o ano que não terminou. In: TELES, E.; SAFATLE, V. (org.) O que resta da ditadura. São Paulo: Boitempo, 2010.

ARENDT, Hannah. Verdade e política. Tradução Manuel Alberto. Lisboa: Relógio Dágua, 1995.

BENJAMIN, Walter. Passagens. Tradução Irene Aron e Cleonice Paes B. Mourão. Belo Horizonte: UFMG, 2018.

BENJAMIN, Walter. Sobre o conceito de história. In: BENJAMIN, Walter. Obras escolhidas: Magia e técnica, arte e politica. Tradução Sérgio Paulo Rouanet. São Paulo: Brasiliense, 1994. v. 1.

CHEUICHE, Alcy. Ana sem terra. Porto Alegre: L\&PM, 2007.

DERRIDA, Jacques. História da mentira: prolegômenos. Estudos Avançados, [s. l.], v. 10, n. 27, 1996. https://doi. org/10.1590/S0103-40141996000200002.

FIGUEIREDO, Eurídice. A literatura como arquivo da ditadura. Rio de Janeiro: 7 Letras, 2017.

GAGNEBIN, Jeanne Marie. O preço de uma reconciliação extorquid. In: TELES, E.; SAFATLE, V. (org.). O que resta da ditadura. São Paulo: Boitempo, 2010.

GAGNEBIN, Jeanne Marie. O que significa elaborar o passado? In: GAGNEBIN, Jeanne Marie. Lembrar escrever esquecer. São Paulo: Ed. 34, 2006 a.

GAGNEBIN, Jeanne Marie. Verdade e memória do passado. In: GAGNEBIN, Jeanne Marie. Lembrar escrever esquecer. São Paulo: Ed. 34, 2006b. 
KEHL, Maria Rita. Tortura e sintoma social. In: TELES, E.; SAFATLE, V. (org.). O que resta da ditadura. São Paulo: Boitempo, 2010.

KUCINSKI, Bernardo. $K$ - relato de uma busca. São Paulo: Cosac Naify, 2014.

PANDOLFO, Alexandre. Apuros - ficção e aforismas contra o estado das coisas. Porto Alegre: Lapices, 2017.

SCHNEIDER, Henrique. Setenta. Porto Alegre: Não Editora, 2019.

SELIGMANN-SILVA, Márcio. Fotografia como arte do trauma e imagem-ação: jogo de espectros da fotografia de desaparecidos das ditaduras na América Latina. Temas em Psicologia, [s. l.], v. 17, n. 2, 2009. https://doi. org/10.20396/resgate.v18i19.8645678.

VECCHI, Roberto. (Re)citando o extremo: o olhar da Medusa, o finito e o infinito do horror. In: SELIGMANN-SILVA, Márcio et al. Escritas da violência: O testemunho. Rio de Janeiro: 7 Letras, 2012.

VIÑAR, Marcelo; VIÑAR, Maren. Exilio e tortura. Tradução Wladimir Lisboa. São Paulo: Escuta, 1992.

\section{Alexandre Pandolfo}

Pesquisador Independente. Doutor em Teoria da Literatura (PUCRS/CNPq). Pós-doutor em Literatura (UFSC/ PNPD-CAPES). Mestre em Criminologia e Controle Social (PUCRS/CAPES). Formado em Ciências Juridicas e Sociais (PUCRS/PIBIC-CNPq). 